PRACE GEOGRAFICZNE

zeszyt $152,2018,67-81$

doi: 10.4467/20833113PG.17.031.8254

Instytut Geografii i Gospodarki Przestrzennej UJ

Wydawnictwo Uniwersytetu Jagiellońskiego

\title{
TERENY NAD WISŁĄ W WARSZAWIE JAKO MIEJSCE SPOTKAŃ (W OPINII MIESZKAŃCÓW WYBRANYCH OSIEDLI)
}

\author{
Katarzyna Duda-Gromada
}

\section{Vistula riverbank areas in Warsaw as a site of gatherings (in the opinion of the inhabitants of selected housing developments)}

Abstract: The presence of a river determines to a large extent the development and shape of a city. The process of revitalization of riverbank areas, which can be seen in cities all over the world, started in the second half of the 20th century. It leads to the creation of new, attractive spaces. In Warsaw too, much has been undertaken to transform the riverbank areas into recreational sites for the city's inhabitants. The purpose of this paper is to present the social importance of riverbank areas in Warsaw. The issue has been discussed on the basis of the results of surveys conducted among the inhabitants of two Warsaw housing developments, as well as of research in the literature and news posted on web portals. Many projects are being implemented in Warsaw, whose main purpose is to increase the attractiveness of the riverbank areas through the improvement of their state of development and esthetics, as well as through the formation of new relationships between the city and the river and the development of diverse forms of activities, especially tourist - and recreation-oriented ones. Moreover, the Capital City of Warsaw markets and promotes these areas. As can be seen from the surveys, public awareness also undergoes changes related to the perception and utilization of the Vistula riverbank areas. Further shaping of these spaces depends not only on the city's authorities, but also on its inhabitants. For that reason, the cooperation between the self-government, public organizations, and business is of essential importance for the creation of the future of these areas.

Keywords: riverbank areas, revitalization, Warsaw, Vistula River 
Zarys treści: Obecność rzeki w znacznym stopniu determinuje rozwój i układ przestrzenny miasta. Od drugiej połowy XX w. rozpoczął się proces rewitalizacji terenów nadrzecznych, który obserwowany jest w miastach na całym świecie. Prowadzi on do powstania nowych, atrakcyjnych przestrzeni. Również w Warszawie w ostatnich latach podjęto wiele działań, aby obszary nadrzeczne stały się miejscem rekreacji mieszkańców. Celem artykułu jest przedstawienie społecznego znaczenia terenów nadrzecznych w Warszawie. Zagadnienie to omówiono na podstawie wyników badań ankietowych przeprowadzonych wśród wybranej grupy mieszkańców dwóch osiedli mieszkaniowych w Warszawie, a także z wykorzystaniem materiałów prasowych zamieszczonych w sieci internetowej oraz publikacji naukowych. Głównym celem realizowanych w Warszawie projektów jest zwiększenie atrakcyjności obszarów nadrzecznych poprzez poprawę ich stanu zagospodarowania i estetyki, a także kształtowanie nowych relacji miasta z rzeką oraz rozwój zróżnicowanych form aktywności, zwłaszcza turystyczno-rekreacyjnych. Ponadto Miasto Stołeczne Warszawa podejmuje działania o charakterze marketingowym. Wyniki badań ankietowych wskazują na zmiany w społecznym postrzeganiu i sposobie użytkowania terenów nad Wisłą. Dalsze kształtowanie tych przestrzeni zależy więc nie tylko od władz miasta, ale również od jego mieszkańców. Dlatego istotne znaczenie ma współpraca między jednostką samorządową, organizacjami społecznymi oraz biznesem w kreowaniu dalszej przyszłości tych terenów.

Stowa kluczowe: tereny nadrzeczne, rewitalizacja, Warszawa, Wisła

\section{Wprowadzenie}

Procesy historycznego rozwoju miast nadrzecznych przebiegały inaczej niż w przypadku miast, które nie były lokowane nad rzekami lub w ich bliskiej odległości. Rzeka wpływa na rozwój miast w wielu wymiarach, między innymi: przestrzennym, urbanistycznym, funkcjonalnym, społecznym i kulturowym (Pancewicz 2003). Położenie nadrzeczne jest czynnikiem nie tylko miastotwórczym. Bezpośredni związek miasta z rzeką w wielu przypadkach stanowi także wartość z punktu widzenia realizacji różnych form aktywności w czasie wolnym jego mieszkańców oraz przyjezdnych.

Celem artykułu jest przedstawienie znaczenia terenów nadrzecznych w Warszawie jako miejsca spotkań towarzyskich oraz rekreacji wybranych grup mieszkańców. Dyskutowane w artykule zagadnienie osadzono w kontekście rewitalizacji tego typu obszarów w dużych miastach. Co prawda w literaturze przedmiotu problematyka ta jest stosukowo często podejmowana, niemniej jednak w niewielkim zakresie uwypukla się aspekt społeczny tego procesu w odniesieniu do rzeki jako elementu składowego krajobrazu miasta. Wyniki badań zaprezentowane w niniejszym artykule mają uzupełnić istniejącą lukę poznawczą. Problematykę społecznej roli terenów nadrzecznych w Warszawie omówiono na podstawie wyników badań ankietowych oraz materiałów prasowych zamieszczonych w sieci internetowej. 


\section{Miasto a rzeka - zarys problematyki}

Już w starożytności w dolinach rzek powstawały i rozwijały się wielkie cywilizacje: Mezopotamii, Egiptu, doliny Indusu czy starożytnych Chin. Ówczesne społeczeństwa były całkowicie uzależnione od rzek poprzez dostęp do wody pitnej, nawadnianie upraw, użyźnianie gleb itp. W średniowieczu obecność rzeki nabrała nowego wymiaru, jakim była naturalna bariera i związana z nią funkcja obronna miasta przed ewentualnymi najeźdźcami (m.in. Ostrowski 2001). W czasach nowożytnych przypisywano rzekom również duże znaczenie w rozwoju miast, zwłaszcza w kontekście transportu rzecznego i możliwości szybkiej wymiany towarów (Szwed 2012). Wraz z rewolucją przemysłową coraz większe znaczenie zyskiwał transport samochodowy, kolejowy, a z czasem lotniczy. Zbyt intensywnie użytkowane rzeki i tereny nad nimi położone stawały się natomiast zaniedbane i zdegradowane. Wówczas nastąpił proces nazywany w literaturze przedmiotu „odwróceniem się miast od rzeki” (Schneider-Skalska 2010; Szwed 2012; Gzell 2015).

Jak wspomniano we wstępie, rzeka miała znaczący wpływ na rozwój miast. Potwierdzają to analizy planów miast nadrzecznych oraz literatury związanej z historią ich rozwoju przestrzennego. Miasta najczęściej lokowane były na jednym brzegu rzeki. Wraz z rozwojem przestrzennym do miasta włączano przedmieścia, a następnie obszary podmiejskie, na końcu zaś dołączano obszary po drugiej stronie rzeki, pamiętając o często długotrwałym procesie integracyjnym (Pancewicz 2003) ${ }^{1}$. Wszystko to sprawiło, że miasta nadrzeczne mają swój niepowtarzalny charakter i wpływa to na ich współczesny wizerunek². Obecnie, kiedy miasta są w fazie przemian, miejsca wyjątkowe, magiczne i unikatowe, naznaczone historią rozwoju całego obszaru mają szczególne znaczenie. W tym świetle walory przestrzeni miejskich nad rzeką zyskują nową wartość.

Powyższy fakt dostrzeżono w drugiej połowie XX w., kiedy rozpoczął się proces rewitalizacji ${ }^{3}$ terenów nadrzecznych (Muszyńska-Jeleszyńska 2013). Na świecie wartość tych obszarów została odkryta „na nowo”, co nabrało znaczenia w kontekście rozwoju miast i wzrostu ich konkurencyjności. W rezultacie poszukuje się nowych czynników aktywizacji rozwoju lokalnego miast związanych z tradycją, historią czy atrakcyjnością ich położenia (Parysek 2005). Rewitalizacja terenów nadrzecznych

\footnotetext{
${ }^{1}$ Szczegółowe informacje dotyczące rozwoju przestrzennego miast znajdujących się nad rzeką, jak również charakterystyki położenia historycznych osad nadrzecznych, usytuowania miast względem brzegów rzeki oraz schematy przestrzennych układów nadrzecznych można znaleźć m.in. w opracowaniach: Pancewicz (2003, 2004) oraz Jażdżewskiej (2011).

${ }^{2}$ Przykładowo jako jeden z symboli Warszawy wskazywana jest warszawska Syrenka (Kwolek, Szmytkie 2007; Dudek-Mańkowska 2011; Derek i in. 2013).

${ }^{3}$ Szerzej o zjawisku rewitalizacji w miastach można przeczytać m.in. w opracowaniach: Kaczmarek (1999, 2001), Lorensa (2010) czy Paryska (2011).
} 
jest zatem ważnym i jednym z podstawowych zadań polityki przestrzennej miast położonych nad rzeką. Niemniej jest to proces złożony i wielowymiarowy (tab. 1). Jak pisze Kowalczyk (2012), w praktyce urbanistycznej do określenia zrewitalizowanych miejskich obszarów nadwodnych, które pełnią inne funkcje niż pierwotnie, używa się terminu waterfront. Koncepcję tę należy zaliczyć w swej istocie do koncepcji urbanistycznych o charakterze planistycznym (Kowalczyk 2012).

$\mathrm{Na}$ świecie zostało zrealizowanych wiele projektów zakładających rewitalizację obszarów nadrzecznych, w tym modelowych (Manchester, Amsterdam i Londyn). Jednym z bardziej znanych przykładów jest rewitalizacja brzegów rzeki Nervión w Bilbao, ale także rzeki Aire w Leeds. W Bilbao tereny byłej stoczni przekształcono w centrum kulturalno-rozrywkowe, a nadbrzeże zostało zagospodarowane obiektami o zróżnicowanych funkcjach, przede wszystkim mieszkaniowych, usługowych i kulturowych (Szwed 2012). W rezultacie stworzono atrakcyjną przestrzeń, co spowodowało ożywienie gospodarcze na tych terenach. Zjawisko to zostało nazwane „efektem Bilbao” (Czarnecka 2010).

Do wielkoobszarowych projektów urbanistycznych zaliczyć można zrealizowanie projektów w takich miastach, jak: Lyon, Hamburg czy Berlin, a w Polsce

Tab. 1. Wymiary procesu rewitalizacji obszarów nadrzecznych w mieście

Table 1. Dimensions of the revitalization process of the city's riverbank areas

\begin{tabular}{|l|l|}
\hline \multicolumn{1}{|c|}{$\begin{array}{c}\text { Wymiar } \\
\text { Dimension }\end{array}$} & \multicolumn{1}{c|}{ Charakterystyczne cechy / Characteristic features } \\
\hline Przestrzenny & $\begin{array}{l}\text { Kreowanie nowego wizerunku poprzez wysoką jakość rozwiązań architektonicznych } \\
\text { i krajobrazowych }\end{array}$ \\
\hline Funkcjonalny & $\begin{array}{l}\text { Określenie nowego przeznaczenia terenu, wprowadzenie współczesnych funkcji } \\
\text { (dopuszczalnych i preferowanych - ściśle określonych) } \\
\text { Zachowanie wielofunkcyjności i zróżnicowanego użytkowania }\end{array}$ \\
\hline Ekonomiczny & $\begin{array}{l}\text { Wywoływanie nowych impulsów rozwoju gospodarczego } \\
\text { Wprowadzenie nowych i rozwój istniejących działalności gospodarczych } \\
\text { Pobudzenie mechanizmów rynkowych, przyciągnięcie inwestorów }\end{array}$ \\
\hline Społeczny & $\begin{array}{l}\text { Społeczeństwo jest podmiotem i uczestnikiem procesu rewitalizacji - aktywizacja } \\
\text { mieszkańców w procesie } \\
\text { Podniesienie poziomu życia } \\
\text { Kształtowanie społecznych relacji z rzeką }\end{array}$ \\
\hline Kulturowy & $\begin{array}{l}\text { Zachowanie tradycji związanych z rzeką - popularyzacja historii związanej z obecnością } \\
\text { rzeki w mieście } \\
\text { Ochrona dziedzictwa historycznego - adaptacja i wykorzystanie zagospodarowania } \\
\text { Rozbudzenie tożsamości lokalnej }\end{array}$ \\
\hline Środowiskowy & $\begin{array}{l}\text { Rekultywacja i oczyszczenie wód i brzegów } \\
\text { Przywrócenie równowagi przyrodniczej na lądzie i w wodzie }\end{array}$ \\
\hline
\end{tabular}

Źródto: opracowanie własne na podstawie: Muszyńska-Jeleszyńska (2013: 103-104).

Source: author's own elaboration, based on: Muszyńska-Jeleszyńska (2013: 103-104). 
np. Gdańsk i Gdynia (Szwed 2012; Muszyńska-Jeleszyńska 2013). Realizacje te (oraz wiele innych) są odzwierciedleniem procesu mającego charakter przestrzenny, ale również społeczny, który w literaturze przedmiotu nazywany jest „,zwróceniem miasta do rzeki”, ,przywróceniem rzeki miastu” itp. (m.in. Schneider-Skalska 2010; Stefanowska 2014; Gzell 2015). Zjawisko to również obserwujemy w miastach nadrzecznych w Polsce, m.in. w Bydgoszczy, Poznaniu, Białymstoku czy w Warszawie.

\section{Warszawa a Wisła - wybrane aspekty relacji}

Środkowy odcinek Wisły jest przykładem krajobrazu dużej, swobodnie meandrującej rzeki, którego charakterystyczne cechy to: wysokie brzegi, piaszczyste plaże, starorzecza, wyspy (Andruszkiewicz 2007; Angiel 2011). Dolina Wisły odgrywa rolę korytarza ekologicznego dla zachowania bioróżnorodności w Europie, a także jest jednym z korytarzy biologicznych, który łączy północ z południem oraz wschód z zachodem. Długość odcinka Wisły znajdującego się w granicach administracyjnych Warszawy liczy $28 \mathrm{~km}$. Wart podkreślenia jest fakt, iż odcinek ten, pomimo rozwoju miasta, nie różni się znacznie od całego środkowego odcinka Wisły. Jest mało uregulowany, co stanowi ewenement w skali europejskiej i znacznie podwyższa atrakcyjność turystyczną i rekreacyjną obszarów nadrzecznych w Warszawie. Dolina Wisły w obrębie Warszawy jest asymetryczna - prawy brzeg jest płaski, natomiast lewy wysoki. W dużej mierze determinuje to sposób zagospodarowywania brzegów Wisły, a także rodzaj podejmowanych aktywności o charakterze rekreacyjnym.

Pierwsze projekty zakładające uporządkowanie i zagospodarowanie brzegów Wisły w Warszawie pochodzą z okresu 1813-1831. Wybuch powstania listopadowego pokrzyżował jednak te plany, a do idei stworzenia bulwarów powrócono w 1844 r. Kolejne etapy w procesie zagospodarowywania warszawskich brzegów Wisły przed II wojną światową w sposób schematyczny przedstawiono w tab. 2.

Po zakończeniu wojny początkowo kontynuowano ideę Prezydenta Starzyńskiego, ale wiele projektów nie zostało zrealizowanych. Po 1989 r. obszar doliny Wisły został podzielony na sześć gmin, co nie było okolicznością sprzyjającą podejmowaniu całościowych decyzji inwestycyjnych, a właśnie takich - ze względu na swoją specyfikę ten obszar wymaga.

Wykorzystywanie rekreacyjne Wisły na terenie Warszawy zaczęło się dużo wcześniej, gdyż już na początku XVIII w. August III organizował festyny na Saskiej Kępie (Bystroń 1977; Handke 2007 za: Stefanowska 2012). Pierwsze formy rekreacji to przejażdżki po Wiśle oraz kąpiele w rzece. Od drugiej połowy XIX w. rozwijały się natomiast aktywności sportowe (Andruszkiewicz 2007; Stefanowska 2012). W tym czasie powstało Warszawskie Towarzystwo Wioślarskie, które organizowało zawody wioślarskie, a także wiele imprez dla mieszkańców miasta. 
Zakładane były kolejne kluby sportowe, dzięki którym Warszawa stała się silnym i ważnym ośrodkiem sportów wodnych (Andruszkiewicz 2007). W tym okresie większość terenów wypoczynkowych Warszawy znajdowała się właśnie nad Wisłą. Wybuch II wojny światowej zahamował rozwój obszarów nadwodnych, ale już w 1945 r. wznowiono kursowanie statków pasażerskich, otwierano plaże miejskie oraz siedziby klubów sportowych. Wówczas przeciętnie było na plażach ok. 2 tys. osób w dni powszednie i 24 tys. osób w dni świąteczne (wg Rocznika Statystycznego Warszawy z 1966 r.; Król 1969). Jeszcze w latach 70. i 80. XX w. organizowane były nad Wisłą liczne imprezy związane ze sportami wodnymi. Nie były to tylko imprezy rekreacyjne dla mieszkańców, ale również zawody sportowe o ogólnoświatowym zasięgu, co świadczy o wysokim poziomie rozwoju sportu i rekreacji oraz odpowiedniej infrastruktury (Andruszkiewicz 2007). W latach 90. w związku ze zmianami społecznymi i politycznymi przestano inwestować w rozwój oraz w utrzymanie istniejącej infrastruktury, a działalność klubów sportowych przeniosła się nad Zalew Zegrzyński.

Tab. 2. Proces zagospodarowywania brzegów Wisły w Warszawie przed II wojną światową Table 2. Development of the banks of the Vistula River in Warsaw before WW II

\begin{tabular}{|c|l|}
\hline Rok (Lata) / Year(s) & \multicolumn{1}{|c|}{ Projekty, realizacje / Projects, implementation } \\
\hline $1813-1831$ & \\
\hline 1844 & - budowa bulwaru z piaskowca na Solcu przez Piotra Steinkellera \\
\hline Lata 50. XIX w. & - nowe plany bulwarów - niezrealizowane \\
\hline $1884-1887$ & \\
\hline 1884 & - budowa Stacji Pomp Rzecznych na Czerniakowie \\
\hline 1904 & $\begin{array}{l}\text { - powstanie Portu Zimowego na Czerniakowie, pierwszego portu rzecznego } \\
\text { w Warszawie }\end{array}$ \\
\hline Od 1925 & - budowa wałów przeciwpowodziowych \\
\hline 1928 & $\begin{array}{l}\text { - powstanie wałów Siekierkowskiego, Potockiego, Golędzinów-Pelcowizna-Żerań } \\
\text { oraz wału między mostem Kierbedzia }{ }^{1} \text { a mostem kolejowym po praskiej stronie }\end{array}$ \\
\hline Okres międzywojenny & $\begin{array}{c}\text { - rozpoczęcie budowy kanału Żerań-Zegrze } \\
\text { - rozpoczęcie realizacji programu „Frontem do Wisły” z inicjatywy Prezydenta } \\
\text { Warszawy Stefana Starzyńskiego } \\
\text { - uporządkowanie Wybrzeża Kościuszkowskiego, plany budowy Wybrzeża } \\
\text { Gdańskiego, wykonanie Wału Miedzeszyńskiego }\end{array}$ \\
\hline
\end{tabular}

Źródto: opracowanie własne na podstawie: Stefanowska (2012: 70-71).

Source: author's own elaboration, based on: Stefanowska (2012: 70-71).

\footnotetext{
${ }^{1}$ Most Kierbedzia - obecnie nieistniejący. Pierwszy stalowy most na Wiśle w Warszawie, wysadzony w 1944 roku. Obecnie znajduje się w tym miejscu Most Śląsko-Dąbrowski.
} 
Zgodnie z tendencjami rozwoju miast nadrzecznych (kolejne etapy relacji między Warszawą a Wisłą w sposób syntetyczny przedstawiono w tab. 3 ) również w Warszawie podjęto działania o charakterze planistycznym, a następnie rewitalizacyjnym. Równocześnie rozwijano inicjatywy społeczne i promocyjne, które miały (i mają) na celu „powrót Warszawy nad Wisłę”. Inwestycje mające szczególne znaczenie w tym procesie to powstanie Centrum Nauki Kopernik (2010 r.), otwarcie Stadionu Narodowego (2011 r.) oraz Multimedialnego Parku Fontann (2011 r.). Ważnym przedsięwzięciem był projekt Warszawski Węzeł Wodno-Rowerowy „Pedałuj i Płyń” (bike\&sail), którego celem było udostępnienie mieszkańcom regionu i turystom atrakcyjnej przestrzeni publicznej nad Wisłą. W ramach tego projektu, obok wspomnianego wcześniej Multimedialnego Parku Fontann, założono stworzenie infrastruktury turystyczno-rekreacyjnej: modernizację i przebudowę lewobrzeżnego bulwaru wiślanego, budowę Nadwiślańskiego Szlaku Rowerowego (NSR), rewitalizację Portu Czerniakowskiego oraz wyposażenie plaż miejskich na praskim brzegu.

Jako odpowiedź na potrzebę zintegrowanych działań została stworzona nieformalna „Dzielnica Wisła”. Projekt realizowany przez Miasto Stołeczne Warszawa ma na celu promocję terenów nad Wisłą. Powstała witryna internetowa (www.dzielnicawisla. um.warszawa.pl), na której mieszkańcy, jak również turyści, mogą znaleźć bieżące informacje na temat różnych wydarzeń, możliwości rejsów po Wiśle, mogą obejrzeć zdjęcia i dowiedzieć się więcej o rozwoju tych obszarów. Należy podkreślić, że nad Wisłą organizowanych jest wiele imprez kulturalnych (np. Wianki nad Wisłą) czy pokazy kina plenerowego. W 2017 r. zostały oddane do użytkowania kolejne części zmodernizowanego bulwaru rzecznego po lewej stronie Wisły. Powstały liczne obiekty gastronomiczne, które w pierwszym sezonie funkcjonowania cieszyły się dużą popularnością.

Tab. 3. Warszawa a Wisła - rozwój relacji w ujęciu historycznym

Table 3. Warsaw and the Vistula - the development of their relationship throughout the history

\begin{tabular}{|c|l|l|}
\hline Okres / Period & \multicolumn{1}{|c|}{ Charakterystyczne cechy / Characteristic features } & \multicolumn{1}{|c|}{ Hasła / Keywords } \\
\hline Początki rozwoju & Wisła jako nieodłączny element krajobrazu miasta & Warszawa otwarta na rzekę \\
\hline I połowa XIX w. & $\begin{array}{l}\text { Okres uprzemysłowienia. Tworzenie na Powiślu } \\
\text { centrum przemysłu i handlu }\end{array}$ & $\begin{array}{l}\text { Proces odwracania się } \\
\text { miasta od rzeki }\end{array}$ \\
\hline Okres międzywojenny & $\begin{array}{l}\text { Granitowy bulwar od Mostu Kierbedzia do Żoliborza. } \\
\text { Otwarcie ZO0 }\end{array}$ & Akcja „Frontem do Wisły” \\
\hline Od lat 90. XX w. & Zmiany społeczne i polityczne - brak inwestycji & - \\
\hline Przełom XX i XXI w. & $\begin{array}{l}\text { Wiele nowych inwestycji } \\
\text { Biblioteka Uniwersytetu Warszawskiego (1998) } \\
\text { Centrum Nauki Kopernik (2010) } \\
\text { Bulwary na lewym brzegu Wisły (od 2015) }\end{array}$ & $\begin{array}{l}\text { Powrót nad Wisłę } \\
\text { "Wisła Warszawa" } \\
\text { "Ciesz się rzeką" }\end{array}$ \\
\hline
\end{tabular}




\section{Tereny nadrzeczne w Warszawie jako miejsce rekreacji}

Tereny nadrzeczne na obszarach miejskich można definiować jako obszary w bezpośrednim sąsiedztwie rzeki, a zatem zagospodarowane fragmenty brzegów. Za ich granicę można przyjąć obrys przyległej zabudowy, zieleni lub innych zespołów obiektów, które mogą być uznane za „ścianę wnętrza krajobrazowego, rozciągającego się wzdłuż rzeki” (Muszyńska-Jeleszyńska 2013: 100). Warto zaznaczyć, że obszary te, chociaż położone w bezpośrednim otoczeniu rzeki, nie zawsze są powiązane z nią funkcjonalnie (Lorens 2004; Pancewicz 2004). Tereny nadrzeczne pełniły w przeszłości wiele funkcji (również o charakterze strategicznym dla rozwoju miasta), które z biegiem czasu i wskutek zachodzących zmian w miastach zanikły. Obecnie poszukuje się nowych możliwości wykorzystania tych obszarów w strukturze przestrzenno-funkcjonalnej miast.

Projekty związane z rewitalizacją obszarów nadrzecznych, także w Warszawie, mają charakter konkretnych działań planistyczno-organizacyjnych oraz inwestycyjnych, których nadrzędnym celem jest odbudowa relacji miasto-rzeka (Muszyńska-Jeleszyńska 2013). Chodzi przede wszystkim o zwiększenie atrakcyjności tych obszarów poprzez poprawę stanu zagospodarowania i estetyki miejsc. Kształtowanie nowych i pożądanych relacji przestrzenno-funkcjonalnych miasta z rzeką, a także rozwój zróżnicowanych form aktywności podejmowanych na tych obszarach. Szczególne znaczenie mają aktywności turystyczno-rekreacyjne, których tradycje nad Wisłą w Warszawie sięgają odległych czasów.

\section{Metodyka badań}

Zmiany w zagospodarowaniu przestrzeni nadrzecznych w Warszawie zaczęły sukcesywnie następować wraz z kolejnymi etapami projektowymi i realizacyjnymi. Proces ten trwa od kilkunastu lat. Zmiany w świadomości społecznej zwykle zachodzą z większym oporem i mniejszą dynamiką . Ważnym zagadnieniem jest społeczne znaczenie warszawskich terenów nadrzecznych. Czy mieszkańcy Warszawy przebywają nad Wisłą? Jakie podejmują aktywności? Jakie są czynniki sprzyjające i ograniczające rekreację na tych terenach? W tym celu przeprowadzono badania o charakterze pilotażowym wśród mieszkańców dwóch osiedli mieszkaniowych w Warszawie. Wybrano Miasteczko Wilanów jako przykład nowego deweloperskiego osiedla mieszkaniowego, zlokalizowanego na terenie lewobrzeżnej Warszawy, oraz Bródno, typowe osiedle z tzw. wielkiej płyty, położone po praskiej (prawej) stronie

${ }^{5}$ Jak wskazują badania przeprowadzone w 2006 r. przez Angiel (2007) na grupie warszawskich licealistów, Wisła jest obecna w ich świadomości, ale niedoceniana jako wyjątkowy walor krajobrazowy miasta. 
Wisły. Osiedla różnią się od siebie przede wszystkim pod względem społecznym. Badanie zostało przeprowadzone na przełomie czerwca i lipca 2015 r. Zastosowano metodę sondażu ulicznego wśród przechodniów o różnych porach dnia, w godzinach przedpołudniowych i popołudniowych. Głównym celem badania była identyfikacja przestrzeni czasu wolnego mieszkańców wybranych osiedli mieszkaniowych na przykładzie Warszawy ${ }^{6}$.

Podczas badania zebrano łącznie 317 prawidłowo wypełnionych kwestionariuszy ankiety, w tym na terenie Miasteczka Wilanów 177, a na Bródnie 140. Wśród respondentów była przewaga kobiet - na Bródnie 59\%, a w Miasteczku Wilanów niespełna 54\%. Większe różnice pomiędzy mieszkańcami obydwu osiedli były zauważalne w odniesieniu do wieku, poziomu wykształcenia oraz statusu materialnego. Respondenci z Miasteczka Wilanów byli młodsi (1,7\% respondentów miało powyżej 65. roku życia, natomiast na Bródnie 23,7\%) i lepiej wykształceni (78,7\% respondentów z Miasteczka Wilanów deklarowało wyższe wykształcenie, a na Bródnie 58\%). Jeżeli chodzi o ocenę stanu materialnego $94,8 \%$ badanych mieszkańców Miasteczka Wilanów określiła ją jako bardzo dobrą lub dobrą. W przypadku mieszkańców Bródna odsetek ten wyniósł 53,1\%.

\section{Wyniki badań}

Z przeprowadzonych badań wynika, że wśród respondentów tylko 13,6\% odwiedza niektóre miejsca nad Wisłą regularnie, 24,3\% na terenach nadrzecznych w Warszawie bywa od czasu do czasu, podobny odsetek badanych deklaruje, iż bywa nad Wisłą rzadko lub sporadycznie, natomiast 37,9\% w ogóle nie spędza czasu wolnego na tych terenach (ryc. 1).

Spędzanie czasu wolnego nad Wisłą deklarowało nieznacznie więcej osób z Miasteczka Wilanów - 14,7\% bywa regularnie, z Bródna natomiast odsetek ten wynosił $12 \%$.

Główne powody spędzania czasu wolnego nad Wisłą, które zostały wskazywane przez respondentów, dotyczą zarówno aktywności podejmowanych na tych terenach, jak i walorów przyrodniczych oraz elementów zagospodarowania rekreacyjno-turystycznego (ryc. 2). Najwięcej badanych wskazało, iż pobyt na terenach nadrzecznych związany jest ze spotkaniami ze znajomymi (139 wskazań, 33\%). Bardzo ważnymi czynnikami przyciągającymi na te obszary okazały się imprezy, wydarzenia o charakterze sportowym i kulturalnym (84 wskazania, 20\%) (ryc. 2; fot. 1). Pewna grupa respondentów przyznała, że „po prostu lubi bywać nad wodą” (70 wskazań, 16,5\%),

\footnotetext{
${ }^{6} \mathrm{~W}$ niniejszym artykule wyniki omawianych badań zostaną przedstawione wybiórczo. Skupiono uwagę na informacjach, które dotyczą terenów nadrzecznych w Warszawie.
} 


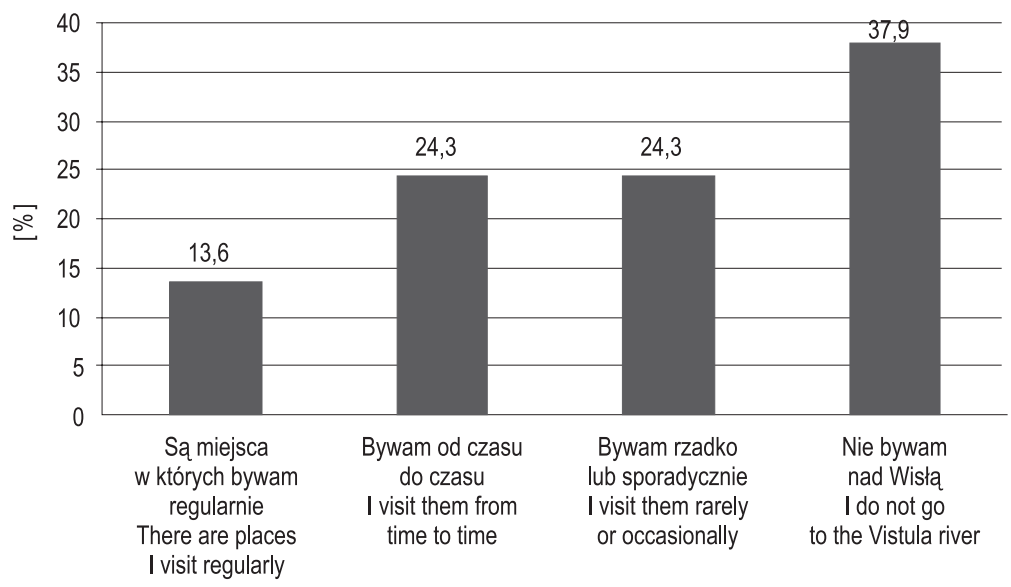

Ryc. 1. Częstotliwość spędzania czasu wolnego nad brzegiem Wisły w Warszawie Fig. 1. Frequency of leisure time spending on the Vistula riverbanks in Warsaw

a walory przyrodnicze w postaci terenów zielonych oraz świeżego powietrza wskazało 47 osób (11\%). Na elementy zagospodarowania związane z poprowadzeniem atrakcyjnych tras rowerowych, możliwością uprawiania sportów wodnych oraz dobrą dostępnością komunikacyjną zwróciło uwagę odpowiednio 29 (7\%), 19 (4,5\%), 14 (3\%) osób (ryc. 2; fot. 2 i 3).

Spośród odpowiedzi zawartych w kategorii „inne”, respondenci wskazywali najczęściej na atrakcyjne trasy spacerowe, spędzanie czasu z dziećmi, możliwość rozpalenia ogniska ${ }^{7}$ oraz łowienia ryb.

Zapytano respondentów również o bariery spędzania czasu wolnego na terenach nadrzecznych (ryc. 3). Najwięcej osób wskazało na zaniedbane wybrzeże (71-15,5\%), brak zagospodarowania $(69-15 \%)$ oraz zanieczyszczenie wody $(67-14,5 \%)$. Poza tym 50 osób (11\%) zwróciło uwagę, że ich zdaniem nad Wisłą w Warszawie nie ma nic ciekawego. Grupa 62 respondentów $(13,5 \%)$ preferuje natomiast inne miejsca na spędzanie czasu wolnego niż warszawskie tereny nadrzeczne.

Wśród kategorii odpowiedzi „inne” pojawiły się takie powody, jak: brak czasu, zbyt duże zatłoczenie i hałas. Warto pamiętać, że od czasu przeprowadzenia omawianych badań kolejne fragmenty bulwaru nadrzecznego po lewej stronie Wisły były remontowane i oddawane do użytkowania. Kolejne, gotowe do użytkowania

\footnotetext{
${ }^{7}$ Miejsca z możliwością rozpalenia ogniska, a także zrobienia grilla, są powszechne na plażach i pozostałych terenach po prawej (praskiej) stronie Wisły. Cieszy się to ogromną popularnością wśród mieszkańców Warszawy, zwłaszcza w popołudnia i wieczory podczas letnich weekendów.
} 


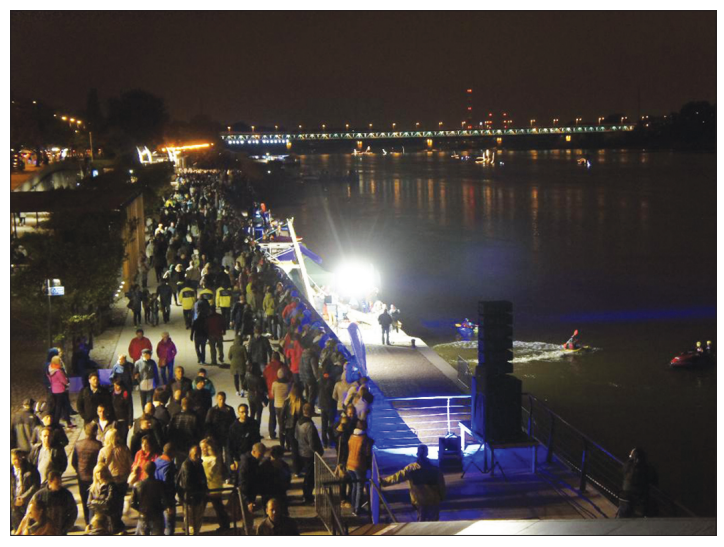

Fot. 1. Festiwal „Święto Wisły” Photo 1. Feast of the Vistula River

Źródto: www.dzielnicawisla.um.warszawa.pl (24.10.2017).

Source: www.dzielnicawisla.um.warszawa.pl (24.10.2017).

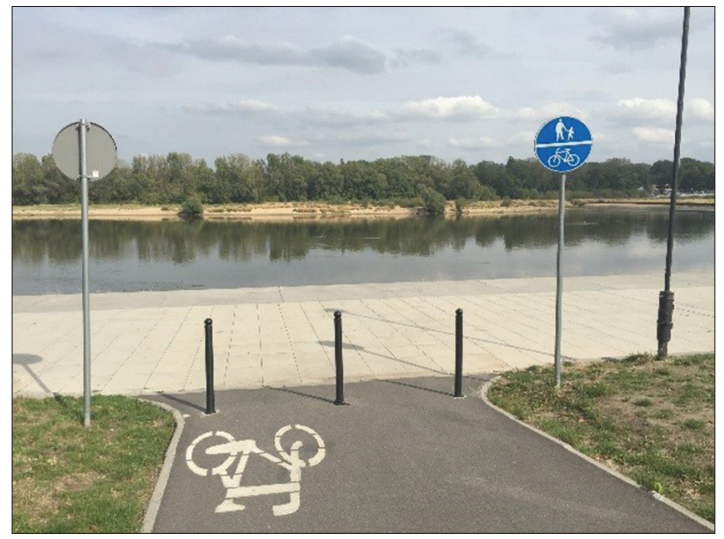

Fot. 2. Szlak rowerowy na lewym brzegu Wisły (fot. K. Duda-Gromada, 2015)

Photo 2. Bicycle trail on the left-hand bank of the Vistula River (photo by K. Duda-Gromada, 2015)

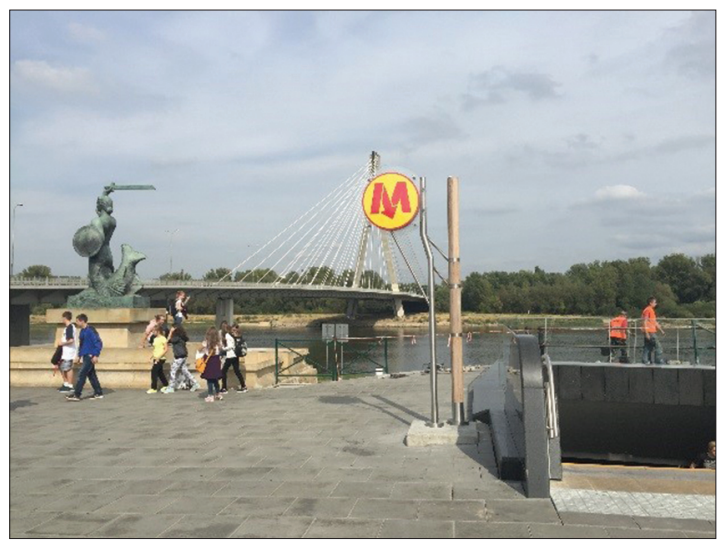

Fot. 3. Dostępność komunikacyjna terenów nadrzecznych w Warszawie wyjście ze stacji metra (fot. K. Duda-Gromada, 2015) Photo 3. Accessibility of transport to the riverbank areas in Warsaw: exit from the underground station (photo by K. Duda-Gromada, 2015) 


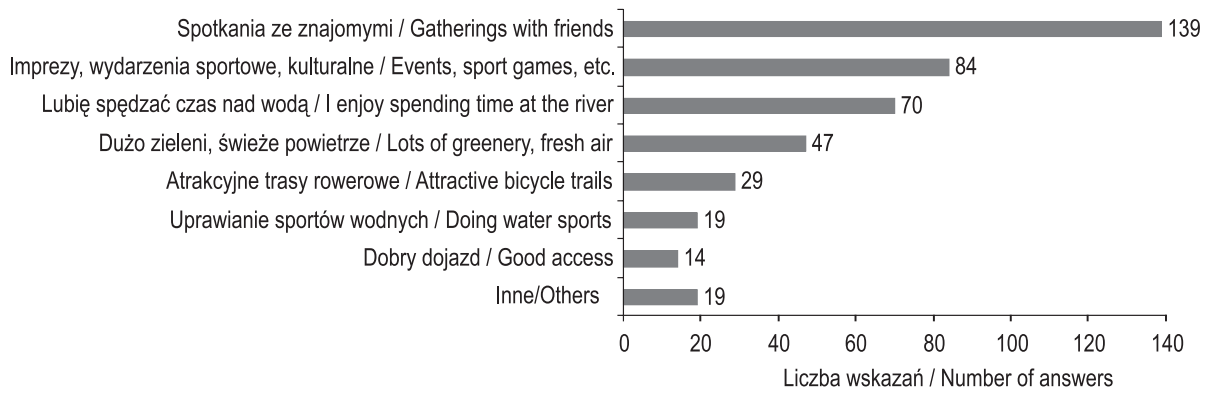

Ryc. 2. Główne powody spędzania czasu wolnego nad Wisłą w Warszawie

Fig. 2. Main reasons for spending leisure time on the Vistula riverbanks in Warsaw

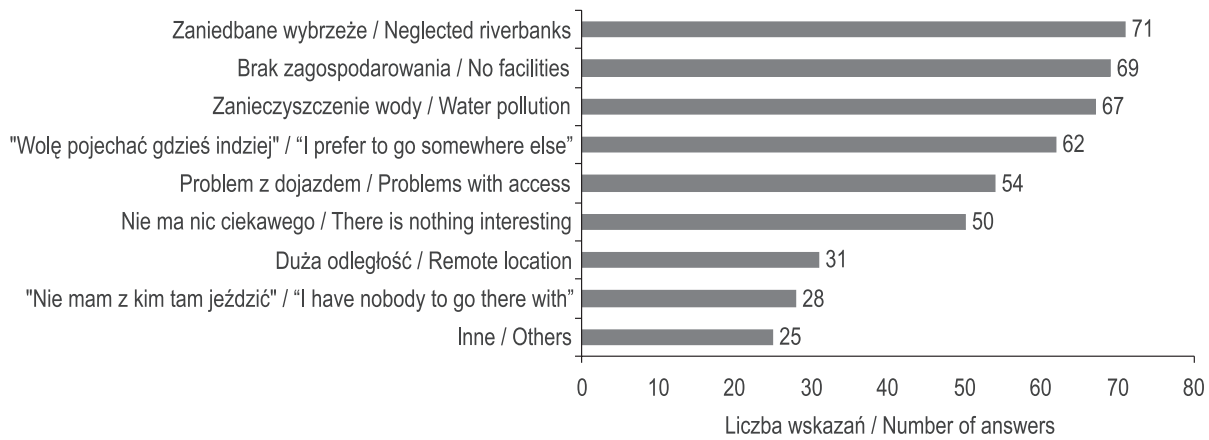

Ryc. 3. Główne bariery spędzania czasu wolnego nad Wisłą w Warszawie

Fig. 3. Main obstacles in spending leisure time in the riverbank areas in Warsaw

odcinki zostały udostępnione w okresie letnim 2017 r. Plany dotyczące ich renowacji i zagospodarowania były znane od dawna, a jednak w świadomości mieszkańców badanych osiedli jeszcze nie do końca się uwidoczniły. Należy jeszcze raz podkreślić, że przeprowadzone badania miały charakter pilotażowy i nie były przeprowadzone na reprezentatywnej grupie mieszkańców. Uzyskane wyniki potwierdzają opinie mieszkańców Warszawy o terenach nadrzecznych i podejmowanych tam aktywnościach. Wyniki omówionych badań można zatem traktować jako punkt wyjścia i ważny przyczynek do prowadzenia dalszych, bardziej szczegółowych analiz. 
Ciekawym uzupełnieniem powyższych wniosków są wyniki badań zachowań i opinii, które zostały przeprowadzone latem 2015 r. przez Biuro Marketingu Miasta. Głównym celem badania było poznanie potrzeb, zachowań i opinii użytkowników brzegów Wisły w Warszawie. Badanie składało się z części kwestionariuszowej (zebrano 3232 ankiety wypełnione przez osoby od 15. roku życia, przebywające nad rzeką w celach rekreacyjnych i rozrywkowych) oraz etnograficznej (13 spacerów etnograficznych, podczas których przeprowadzono obserwacje i wywiady) ${ }^{8}$. Badania wykonano w najczęściej uczęszczanych terenach nadrzecznych, zarówno po prawej, jak i po lewej stronie Wisły. Z badań wynika, że użytkownicy tych obszarów pochodzą z różnych części miasta. Wyraźnie jednak widać, że największy odsetek badanych mieszka w dzielnicach, które położone są nad rzeką i mają najlepszy dostęp do najbardziej atrakcyjnych miejsc (Śródmieście - 15\%, Praga Południe - 14\%, Praga Północ - 9\%). Deklarowane cele przyjścia nad Wisłę w dużej mierze pokrywają się z wynikami wcześniej opisanych badań. Są to przede wszystkim: wypoczynek $-44 \%$, spotkania towarzyskie - 35\%, spacer - 33\%. Podobna sytuacja występuje w odniesieniu do czynników zniechęcających do rekreacji nad Wisłą. Wskazywano na zanieczyszczenie rzeki (59\%), a także jej niebezpieczeństwo (57\%), nieprzydatność do pływania (86\%) czy uprawiania sportów wodnych (26\%). Respondenci skarżyli się także na problem śmieci i hałasu. Jako rekomendacje sugerowali zagospodarowywanie brzegów w obiekty i usługi, takie jak: toalety - 43\%, ławki - 33\%, kosze na śmieci $-27 \%$, kawiarnie, puby $-13 \%$, restauracje - 10\% itd. Zmiany, które zachodzą w ostatnim czasie na terenach nadrzecznych, będące efektem realizowanych inwestycji, są dobrze oceniane przez respondentów (82\%).

Omówione wyżej wyniki badań przeprowadzonych wśród mieszkańców dwóch warszawskich osiedli oraz użytkowników przestrzeni nadrzecznych w Warszawie potwierdzają, że również w świadomości społecznej zachodzą zmiany związane z postrzeganiem tych terenów. Zmiany te jednak zachodzą wolniej i wymagają wielu zabiegów o charakterze marketingowym i promocyjnym, aby coraz więcej mieszkańców spędzało swój wolny czas nad Wisłą. Miasto Stołeczne Warszawa stara się promować rekreację nad Wisłą, chociażby poprzez realizację projektu „Dzielnica Wisła”. Poza tym, na podstawie przeprowadzonych w Urzędzie analiz, stworzono komunikat „parasolowy” dla Wisły na lata 2016-2020, którego myślą przewodnią jest hasło „Wisła należy do nas”. Oznacza to, że „Nad Wisłą każdy może wypoczywać tak, jak chce i razem z innymi kształtować to miejsce” (Strategia komunikacji...).

Warto również nadmienić, że 2017 r. został ogłoszony przez Sejm RP „Rokiem Rzeki Wisły”. Dlatego w całej Polsce podjęto wiele działań promujących Wisłę.

\footnotetext{
${ }^{8}$ Więcej informacji na temat samego badania i jego wyników można uzyskać z broszury Warszawska Wista oczami jej użytkowników opracowanej przez Biuro Marketingu Miasta, www.dzielnicawisla.um.warszawa. pl (24.10.2017).
} 
Niektóre z nich mają charakter społeczny i często oddolny. Są to inicjatywy ludzi i organizacji pozarządowych, a głównym ich celem jest budowa dobrej marki rzeki Wisły. Jednym z trwałych efektów mają być projekty, cykliczne działania, tworzenie produktów turystycznych, kulturalnych i społecznych, które będą miały charakter nie tylko lokalny, ale także ogólnokrajowy (www.rokwisly.pl, 6.11.2017).

\section{Zakończenie}

Rozwój przestrzenno-funkcjonalny miast nadrzecznych w dużej mierze zdeterminowany jest przez rzekę. „Dolina rzeki stanowi rodzaj przekroju miasta, pokazującego zarówno fazy rozwoju, przemiany dziejowe, jak i wpływ na życie jego mieszkańców, jest więc naznaczona duchem czasu” (Pancewicz 2004: 43). Dlatego tak ważnym zagadnieniem w ostatnich dziesięcioleciach jest rewitalizacja obszarów nad rzeką w mieście. Na całym świecie proces „zwracania się miast ku rzece” nabiera coraz większego znaczenia i podejmowanych jest wiele inwestycji, często o bardzo dużym zasięgu i zróżnicowaniu. Dlatego wielu badaczy zajmuje się tą tematyką, czego pokłosiem jest bogata literatura przedmiotu. Procesy te obserwujemy również w polskich miastach, które mają nadrzeczne położenie. Takim przykładem jest m.in. Warszawa, której więcej uwagi poświęcono w niniejszym artykule.

Bez wątpienia przestrzeń terenów nadrzecznych w Warszawie w ostatnich latach ulega wielu zmianom. Zmiany te zachodzą w różnych kontekstach - architektonicznym i urbanistycznym, przestrzenno-funkcjonalnym, estetycznym i kulturowym. Warto zwrócić uwagę, że dalsze kształtowanie tych przestrzeni zależy nie tylko od władz miasta, ale również od jego mieszkańców. To mieszkańcy są głównym adresatem wprowadzanych zmian i jednocześnie główną grupą użytkowników. Dlatego istotne znaczenie ma współpraca między jednostką samorządową, organizacjami społecznymi oraz biznesem w kreowaniu dalszej przyszłości tych terenów. Ponieważ sytuacja na terenach nadrzecznych ulega dynamicznym przemianom - czego przykładem jest chociażby Warszawa - należy podejmować badania w tym obszarze, gdyż problematyka ta jest wciąż aktualna.

„Każdy ma swoją Wisłę, bo Wisła to przestrzeń publiczna, która pozwala użytkownikom na znalezienie własnych „swojskich miejscówek”. Wisła nie wyklucza, jest demokratyczna i egalitarna, panuje tutaj równość oraz pewność, że każdy znajdzie coś dla siebie, bez względu na zasobność portfela" (Warszawska Wista...). 


\section{Literatura}

Andruszkiewicz A., 2007, Wista - sciek czy skarb przyrody? Szanse dla rozwoju turystyki i rekreacji na warszawskim odcinku Wisty, Turystyka i Rekreacja, 3, 50-55.

Angiel J., 2007, Postræeganie rzeki Wishy jako elementu krajobrazu miasta i jego znaczenie w edukacji geografičnej, [w:] M. Madurowicz (red.), Percepcja wespótčesnej præestræeni miejskiej, Wyd. WGiSR UW, Warszawa, 299-307.

Angiel J., 2011, Rzeka Wista, jej wartości i percepcja. Wista w edukacji geograficænej, Wyd. WGiSR UW, Warszawa.

Bystroń J., 1977, Warszawa, PIW, Warszawa.

Czarnecka D., 2010, Relacja ræeka-miasto, Wydział Architektury Politechniki Warszawskiej, Warszawa.

Derek M., Duda-Gromada K., Kosowska P., Kowalczyk A., Madurowicz M., 2013, Problemowe i problematyczne ABC turystyki w Warszawie, Prace Geograficzne, 134, 7-36.

Dudek-Mańkowska S. 2011, Wizerunek Warszawy w dziataniach promocyjnych władz lokalnych i swiadomości spotecznej, Wydawnictwa Uniwersytetu Warszawskiego, Warszawa.

Gzell S., 2015, Nadwodna lokalizacja - co to dziś oznacza dla miasta?, Przestrzeń i Forma, 24/1, $113-128$.

Handke K., 2007, Przyczyny odmienności lewo- i prawobrzeżnej Warszawy, [w:] A. Stawarz (red.), Miasto po obu stronach rzeki - różne oblicza kultury, Muzeum Historyczne m.st. Warszawy, Muzeum Niepodległości w Warszawie, Warszawa, 215-220.

Jażdżewska J., 2011, Rzeki jako bariery w kštałtowaniu miejskiej sieci osadničej Polski w świetle zastosowań Systemów Informacji Geograficznej, [w:] S. Kaczmarek (red.), Miasto. Ksiega jubileusะowa w 70. rocznicę urodzin Profesora Stanistawa Liszeweskiego, Wydawnictwo Uniwersytetu Łódzkiego, Łódź, 155-177.

Kaczmarek S., 1999, Rewitalizacja a organiæacja præestræeni miejskiej, [w:] XII Konwersatorium Wiedzy o Mieście, Łódź, 43-51.

Kaczmarek S., 2001, Rewitalizacja terenów poprzemystowych. Nowy wymiar w rozwoju miast, Wydawnictwo Uniwersytetu Łódzkiego, Łódź.

Kowalczyk A., 2012, Recepta na sukces? Znaczenie koncepcji waterfrontu dla rozwoju turystyki w miastach. Przyktad z Hongkongu, [w:] J. Kowalczyk-Anioł, M. Makowska-Iskierka (red.), Turystyka. Moda na sukces. Warsztaty z Geografii Turyzmu, Wydawnictwo Uniwersytetu Łódzkiego, Łódź, 21-47.

Król B., 1969, Wypoczynek warszawiaków, [w:] S. Nowakowski (red.), Warsæawa. Socjologiczne problemy stolicy i aglomeracji, Książka i Wiedza, Warszawa.

Kwolek J., Szmytkie R., 2007, Symbole du:zych miast w opinii studentow, [w:] M. Madurowicz (red.), Percepcja wspótczesnej przestrzeni miejskiej, Wyd. WGiSR UW, Warszawa, 243-253.

Lorens P., 2004, Rewitalizacja frontów wodnych jako element procesu odnowy miast, [w:] K. Markowski (red.), Præestræeń wa zaræadzaniu rozwojem regionalnym i lokalnym, Biuletyn KPZK PAN, 211, 179-204. 
Lorens P., 2010, Rewitalizacja miast. Planowanie i realizacja, Wydział Architektury Politechniki Gdańskiej, Gdańsk.

Muszyńska-Jeleszyńska D., 2013, Tereny nadræeczne w aspekcie rozwoju i rewitalizacji miast, Journal of Health Sciences, 3 (14), 99-107.

Ostrowski W., 2001, Wprowadzenie do historii budowy miast. Ludzie i środowisko, Oficyna Wydawnicza Politechniki Warszawskiej, Warszawa.

Pancewicz A., 2003, Rola rzek w rowwoju przestrzennym historycznych miast nadræecznych, [w:] Woda w præestræeni przyrodnic«ej i kulturowej, Prace Komisji Krajobrazu Kulturowego, II, Sosnowiec, 275-285.

Pancewicz A., 2004, Rzeka w krajobra ie miasta, Politechnika Śląska, Gliwice.

Parysek J.J., 2005, Miasta polskie na præetomie XX i XXI wieku. Rowwój i præeksstałcenia strukturalne, Bogucki Wydawnictwo Naukowe, Poznań.

Parysek J.J., 2011, Rewitalizacja miast w Polsce.Refleksja retrospektywna i perspektywiczna, [w:] S. Kaczmarek (red.), Miasto. Ksiega jubileuszowa w 70. rocznice urodzin Profesora Stanistawa Liszereskiego, Wydawnictwo Uniwersytetu Łódzkiego, Łódź, 81-93.

Rocænik Statystyczny Warszawy, 1966, Wydział Statystyki, Miejski Urząd Statystyczny Miasta Stołecznego Warszawy, Warszawa.

Schneider-Skalska G., 2010, Projektowanie zrównoważone terenów nadrzecznych w miastach, [w:] B. Więzik (red.), Prawne, administracyjne i środowiskowe uwarunkowania zagospodarowania dolin rzecznych, Wyższa Szkoła Administracji w Bielsku-Białej, Bielsko-Biała, 191-199.

Stefanowska A., 2012, Zagospodarowanie rekreacyjne Wisty na jej warszawskim odcinku - historia i perspektywy, Problemy Turystyki i Rekreacji, 1, 69-79.

Stefanowska A., 2014, Rola rweki w rowwoju turystyki miejskiej na przykładzie Warszawy i wybranych miast europejskich, Turystyka Kulturowa, 8, 6-18.

Strategia komunikacji Wisty 2016-2020, www.dzielnicawisla.um.warszawa.pl (6.11.2017).

Szwed J., 2012, Wspótczesna rola bulwarów w mieście, Przestrzeń i Forma, 16, 443-457.

Warszawska Wista ocะami jej użytkowników. Badanie zachowań $i$ opinii, lato 2015, www.dzielnicawisla.um.warszawa.pl (24.10.2017).

www.dzielnicawisla.um.warszawa.pl (24.10.2017).

www.rokwisly.pl (6.11.2017).

Katarzyna Duda-Gromada

Uniwersytet Warswaweski

Wydziat Geografii i Studiów Regionalnych

ul. Krakowskie Præedmieście 30, 00-927 Warsะawa

kduda@uw.edu.pl 
